\title{
Diversity of Ganoderma spp. and falls of urban trees in Brazil and Colombia
}

Keywords: urban trees, sound pollution, climate changes, wooddegrading fungi, environmental conditions, mushrooms

\section{Introduction}

Urban trees bring several benefits for the wellbeing of the population: for example, they regulate microclimate, provide shade, break the wind, decrease sound pollution, sequester and store carbon, and intercept rain water. ${ }^{1-4}$ Constant variables directly interfere with the urban trees, such as water stress, lack of permeable area in the root collar and roots, inadequate pruning, roots cut, mechanical shocks, floods during the rainy season, attacks of insects (termites and beetles) and wood-degrading fungi. Climate changes have triggered more intense phenomena and in the rainy season storms and strong winds are frequent, causing an increase in the occurrences of trees falling because of rotten trunks due to fungi attacks and other xylophageous organisms. ${ }^{5}$

During 2016, up to November $16^{\text {th }}, 2,907$ trees fell, according to the System of Management of Critical Occurrences (SGOC - acronym in Portuguese) of the Municipal Department of Coordination of the Prefecture of São Paulo. Tree falls in densely-populated urban centers are a probable hazard for people, vehicles and properties. Ganoderma is a cosmopolitan mushroom genus with 60-80 lacquered species and 30-40 non-lacquered species. ${ }^{6}$ It is found in conifer and angiosperm groves in North America and Canada, ${ }^{7}$ in China and Europe. ${ }^{8}$ Species of the genus occur in eastern Africa, ${ }^{9}$ tropical Asia (Imazeki 1939), in Malaysia ${ }^{10}$ and in the Neotropics. ${ }^{11-13}$ Ganoderma species in tropical regions are less well studied and phylogenetic studies have been published only in the last few years (Lima junior et al 2014). ${ }^{14-21}$ The tropical regions probably are the origin of this genus once a large number of taxa have been described in the tropics. It is believed that there has been an irradiation from the equatorial regions toward other regions and that environmental condition determined a high biological diversity ${ }^{22}$ of these mushrooms.

\section{Conclusion}

Recently the development of next-generation sequencing technologies has enabled sequencing complete genome of the species G. lucidum, G. meredithiae and G. applanatum. ${ }^{27,28}$ In two recent $\mathrm{phD}$ thesis, ${ }^{29,30}$ eight Ganoderma species (G. australe (Fr.) Pat., G. gibbosum (Blume \& T. Nees) Pat., G. multiplicatum (Mont.) Pat., G. orbiformum (Fr.) Ryvarden, G. parvulum complex, G. perzonatum Murrill, G. subamboinense (Henn.) Bazzalo \& Wrigth and $G$. stipitatum (Murrill) Murrill have been identified infecting ten species of leguminous trees (Bauhinia purpurea L., Caesalpinia ferrea Mart. ex Tul., C. peltophoroides Benth, Cassia fistula L., Leucaena leucocephala (Lam.) de Wit., Inga edulis Mart., I. vera Kunth, Phitecelobium dulce (Roxb.) Benth, Poincianella pluviosa (DC) L.P. Queirozand Tipuana tipo (Benth) Kuntze) in public streets in cities in tropical and sub-tropical regions, such as São Paulo (Figure 1) (Figure 2), Uberaba and Campo Grande in Brazil, and Cali in Colombia. These studies suggest clear susceptibility of leguminous trees to Ganoderma species but there is no fungus-host specificity. Further studies are needed to determine the risk of infected trees to fall down when the fungus is present.
Volume 2 Issue 2 - 2018

\author{
Ana Cristina Bolanõs Rojas,' Luci Quimio \\ Okino Silva, ${ }^{2}$ Adriana de Melo Gugliotta, ${ }^{2}$ \\ Vera Lucia Ramos Bononi ${ }^{3}$ \\ 'Universidad del Vale, Colombia \\ ${ }^{2}$ Instituto de Botanica de São Paulo, Brazil \\ ${ }^{3}$ University Anhanguera/Uniderp, Brazil
}

Correspondence: Vera Lucia Ramos Bononi, University Anhanguera/Uniderp, Instituto de Botanica de São Paulo, Brazil, Email vbononi@uol.com.br

Received: February 27, 2018| Published: April 16, 2018

Ryvarden $\mathrm{L}^{13,23}$ described 20 lacquered species of Ganoderma for several regions of the Neotropics. For Brazil, lacquered and nonlacquered species have been mentioned, including species deemed restricted to Europe, such as G. lucidumand, G. applanatum. ${ }^{24}$ In Colombia, the genus has been less studied; however, morphologybased studies mention the existence of G. australe, G. adspersum, $G$. amazonense, G. applanatum, G. brownie, G. chalceum, G. concinnum, G. fornicatum, G. lucidum, G.multiplicatum, G. nitidum and, G. neurosporum. ${ }^{13,25,26}$ The proliferation of the Ganoderma species is due to pleomorphic characters dependent of environmental conditions and phase of development. Young Ganoderma Basidiomas that are actively growing generally have clearer and brighter colors than specimens several days or weeks old, exposed to repeated periods of rain or drought, covered with dust, attacked by insects or colonized by algae. ${ }^{6}$ The genus probably is one of the Polypores fungi groupthat is taxonomically more confusing; there are over 250 nomenclatural combinations published. ${ }^{22}$
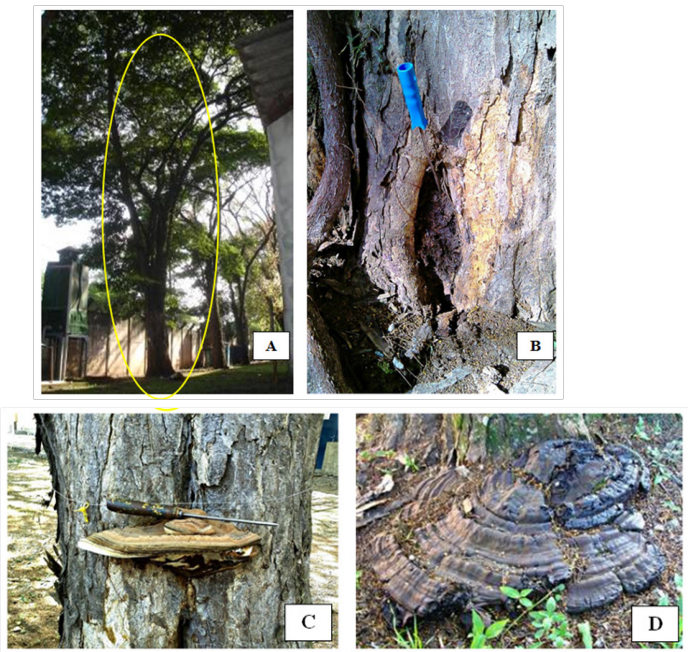

Figure I (A)Tree forsuppression.(B) wound with intense decay. (C) Basidioma of Ganoderma sp. no boom. (D) Basidioma of Ganoderma sp. in the root. 


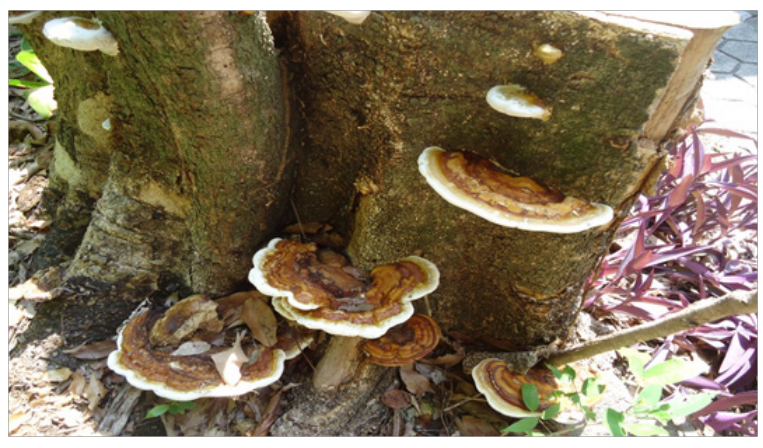

Figure 2 Ganoderma sp. Photo AM Gugliotta, 2017.

\section{Acknowledgements}

FAPESP (Fundação de amparo a pesquisa do Estado de São Paulo)

\section{Conflict of interest}

Authors declare there is no conflict of interest in publishing the article.

\section{References}

1. Shigo AL. Tree decay: an expanded concept. Washington: USDA, Agriculture Forest Service; 1979.

2. Nowak DJ, Crane DE. Carbon storage and sequestration of urban trees in the USA. Environmental Pollution 2002;116(3):381-389.

3. SVMA. Manual Técnico de Arborização Urbana. Prefeitura de São Paulo; 2015. $124 \mathrm{p}$

4. Pradella DZA, Silva JWF, Nisi TCC. Arborização Urbana. 1st ed. São Paulo: SMA/CEA; 2015.

5. Brazolin S. Biodeterioração, anatomia do lenho e análise de risco de queda de árvores de tipuana, Tipuana tipu (Benth.) O. Kuntze, nos passeios públicos da cidade de São Paulo, SP. Tese de Doutorado, Piracicaba: Escola Superior de Agricultura Luiz de Queiroz, Universidade de São Paulo; 2009. 265 p.

6. Moncalvo JM. Systematics of Ganoderma. In: Flood J, Bridge PD, editors. Ganoderma diseases of perennial crops. CAB International, Wallingford, UK; 2000. p. 23-45.

7. Gilbertson RL, Ryvarden L. North American Polypores. Part 1. Fungiflora, Oslo; 1986.

8. Ryvarden L. Can we trust morphology in Ganoderma? In: Buchanan RK, Hseu RS, editors. Ganoderma: systematics, phytopathology and pharmacology. Proceedings of Contributed Symposium 59A, B, 5th International Mycological Congress, Vancouver, Taipei: National Taiwan University; 1995. p. 19-24

9. Ryvarden L, Johansem I. A preliminarypolypore flora of east Africa. Fungiflora,Oslo; $1980.636 \mathrm{p}$.

10. Corner EJH. Ad Polyporaceas I. Amauroderma and Ganoderma. Beiheft Nova Hedwigia 1983;75:1-182.

11. Donk MA. Revision der NiederlandischenHomobasidiomycetaeAphyllophoraceaeII. Med Bot Mus. Rijksuniv Utrecht. 1933;9:1-27.

12. Furtado JS. Relation of micro structures to the taxonomy of the Ganodermoideae (Polyporaceae) with special reference to the structure of the cover of the pilearsurface. Mycologia. 1965;57:588-611.
13. Ryvarden L. Neotropical Polypores: Part 1. Introduction, Ganodermataceae \& Hymenochaetaceae. Synopsis Fungorum. 2004;19:1-227.

14. Flores JA, Barnes CW, Ordoñez ME. Ganoderma podocarpense sp. nov. Persoonia. 2017;39:299.

15. Zothanzama J, Blanchette H, Barnes CW. Ganoderma mizoramense sp. nov. Persoonia. 2017;38:327.

16. Coetzee MPA, Marincowitz, S, Muthelo VG, et al. Ganoderma species, including new taxa associated with root rot of the iconic Jacaranda mimosifolia in Pretoria, South Africa. IMA Fungus. 2015;6(1):249-256.

17. Xing JH, Song J, Decock C, Cui BK. Morphological characters and phylogenetic analysis reveal a new species with in the Ganoderma lucidum complex from southafrica. Phytotaxa. 2016;266(2):115-124.

18. Cao Y, Yuan HS. Ganoderma mutabile sp. nov. From south western China based on morphological and molecular data. Mycol Progress. 2011;12(1):121-126.

19. Torres-Torres MG, Guzmán-Dávalos L, Gugliotta AM. Ganoderma viviamercedianum sp. nov and related species G. perzonatum. Mycotaxo. 2008;105:447-454.

20. Kinge TR, Mih AM. Ganoderma ryvardense sp. nov. Associated with basal stem rot (BSR) disease of oil palm in Cameroon. Mycosphere. 2011;179-187.

21. Douanla-Meli C, Langer E. Ganoderma carocalcareus sp. nov., with crumbly-friable context parasite to saprobe on Anthocleista nobilis and its phylogenetic relationship in G. resinaceum group. Mycological Progress. 2009;8(3):145-155.

22. Moncalvo JM, Wang HF, Hseu RS. Phylogenetic relationship in Ganoderma inferred from the Internal Transcribed Spacers and 25S Ribossomal DNA sequences. Mycologia. 1995;87(2):223-238.

23. Ryvarden L. Studies in Neotropical polypores 2: a preliminary key to neitropical species of Ganoderma with a laccatepileus. Mycologia. 2000;92:180-191.

24. Gugliotta AM, Abrahão MC, Gibertoni TB. Polyporales in Lista de Espécies da Flora do Brasil. Jardim Botânico do Rio de Janeiro; 2013.

25. Vasco-Palacios AM, Franco-Molano AE. Diversity of Colombian Macrofungi.(Ascomycota-Basidiomycota). Mycotaxon. 2013;121:499.

26. Bolaños AC. Diversidade do gênero Ganoderma Karst. (Ganodermataceae) e atividade enzimática de espécies que ocorrem em leguminosas. Tese de Doutorado, São Paulo: Instituto de Botânica, Secretaria do Meio Ambiente; 2016. 145 p.

27. Wang XC, Shao J, Liu C. The complete mitocondrial genome of the medicinal fungus Ganoderma applanatum (Polyporales, Basidiomycota). Mitochondrial DNA. 2016;27(4):2813-2814.

28. Wang $\mathrm{XC}, \mathrm{Wu} \mathrm{K}, \mathrm{Chen} \mathrm{H}$, et al. The complete mitocondrial genome of the white-rot fungus Ganoderma meredithiae (Polyporales, Basidiomycota). Mitochondrial DNA. 2016;27(6):4197-4198.

29. Bolaños AC, Bononi VL, Gugliotta AM, et al. New records of Ganoderma multiplicatum (Mont.) Pat. (Polyporales, Basidiomycota) from Colombia and its geographic distribution in South America. Check list of theBiodiversity data. 2016;12(4):1-7.

30. Quimio-Silva LO. Avaliação da decoomposição por fungos Ganoderma spp (Polyporales, Basidiomycota emsibipirunas (Poincianella pluviosa) LP queiroz) da arborização urbana da cidade de São Paulo. Tese de Doutorado, São Paulo: Instituto de Botânica, Secretaria do Meio Ambiente; 2017. 